\title{
40. MINERALOGY AND GEOCHEMISTRY OF THE CRETACEOUS/TERTIARY BOUNDARY IN DEEP SEA DRILLING PROJECT HOLES 465 AND $465 A^{1}$
}

\author{
Patrick Giblin, ${ }^{2}$ Institut de Géologie, Université Louis Pasteur, 1, rue Blessig, F-67084 Strasbourg Cedex, France
}

\section{INTRODUCTION}

The complete Paleocene section begins with the basal Tertiary Globigerina eugubina Zone. This zone occurs at $465 \mathrm{~A}-3-3,4 \mathrm{~cm}$ to $465 \mathrm{~A}-3-3,144 \mathrm{~cm}$ and belongs to Lithologic Unit I (Site 465 report, this volume), a homogeneous, white, moderately to highly disturbed nannofossil ooze.

Eleven samples spanning the Cretaceous/Tertiary boundary were analyzed by X-ray diffraction and spectrometry.

\section{METHODS}

$\mathrm{X}$-ray analyses of bulk samples were performed on a Phillips X-ray diffractometer under the following instrumental conditions: $\mathrm{CuK} \alpha$ radiation, $\mathrm{Ni}$ filter, $38 \mathrm{Kv}, 18 \mathrm{~mA}, 1 \% \mathrm{~min}$. Semi-quantitative estimation was made by comparison of (001) peaks of minerals on X-ray diffractograms. Samples for clay-fraction analyses were first treated with dilute hydrochloric acid $(0.1 N)$ to remove carbonates, according to the method described by Robert and Tessier (1974). Oriented clay aggregates are ethylene glycol and hydrazine treated and heated according to the methods of the Institut de Géologie, Strasbourg (Weber and Larque, 1978).

Semi-quantitative estimations of the amounts of clay minerals were made on the glycolated X-ray charts under the following conditions: $\mathrm{CuK} \alpha$ radiation, $\mathrm{Ni}$ filter, $40 \mathrm{Kv}, 20 \mathrm{~mA}, 2 \% \mathrm{~min}$.

Chemical analyses of major elements $(\%)$ and trace elements (ppm) on bulk samples were performed on an Arl-Sofica quantometer, by arc spectrometry, according to the methods described by Ataman and Besnus (1965), Besnus and Lucas (1970), and Besnus and Rouault (1973). Concentrations of $\mathrm{K}$ and $\mathrm{Na}$ in solution were measured with the flame EEL 450 (Corning Medical) spectrophotometer. The relative precision is $\pm 2 \%$ for major elements and $\pm 20 \%$ for trace elements.

\section{MINERALOGY}

\section{Bulk Samples}

Lithologic Unit I in Holes 465 and $465 \mathrm{~A}$ is a homogeneous nannofossil and foraminifer-nannofossil ooze at the Cretaceous/Tertiary boundary. X-ray data (Table 1) show that the sediments contain mostly calcite and quartz. No opal-CT was found; quartz represents chert in Unit I. Goethite is associated with calcite.

\section{Clay Minerals}

Two samples (465-7, CC and 465A-3-6, 30-32 cm) with high carbonate contents provided no clays.

The prevalent clay minerals are smectites (Fig. 1), and their crystallinity differs in the two holes: in Hole

\footnotetext{
${ }_{1}^{1}$ Initial Reports of the Deep Sea Drilling Project, Volume 62.

2 Present address: Sociéte Nationale Elf Acquitaine, Centre Micoulau, BP 65, 64000 Pau, France.
}

465 , Core 10, smectite crystallinity is good; it is bad in the upper Maastrichtian sediments of Hole 465A.

Attapulgite occurs in all samples in small amounts. Sepiolite occurs only in a carbonate-rich sample (465$10-2,70-72 \mathrm{~cm})$, associated with clinoptilolite. This clinoptilolite was detected only on the $<2-\mu \mathrm{m}$ X-ray diffractogram. Clinoptilolite is common in Cretaceous pelagic sediments (Stonecipher, 1976) and often associated with attapulgite and chert.

Some lath structures in the clay fraction have been observed (Plate 1). Micro-diffraction diagrams show that these are not palygorskite fibers, but are characteristic of clay monocrystals with the sheets orientated perpendicular to the electron beam. These clay minerals, according to X-ray diffraction, are smectite, but since we have no chemical analyses of the $<2 \mu \mathrm{m}$ fraction, we are not able to specify which kind of smectite they are.

\section{GEOCHEMISTRY}

In Unit I, carbonates are represented by coccoliths and foraminifers, and $\mathrm{CaO}$ contents are very high (42$55 \%)$, except in one sample $(465 \mathrm{~A}-4, \mathrm{CC})$ where goethite occurs and the $\mathrm{Fe}_{2} \mathrm{O}_{3}$ content represents $40 \%$ of bulk material.

Many trace elements are lower than the detection limits, such as $\mathrm{V}, \mathrm{Co}, \mathrm{Cr}, \mathrm{Zn}$, and $\mathrm{Ga}$ (Table 2). The high contents of $\mathrm{Sr}$ and $\mathrm{Ba}$ are associated in part with the carbonates; the correlation coefficients between $\mathrm{Ca}$ and $\mathrm{Sr}(r=0.60)$ and $\mathrm{Ca}$ and $\mathrm{Ba}(r=0.16)$ are not significantly below their theoretical correlation coefficient $(r=0.68)$. Some samples are enriched in $\mathrm{SiO}_{2}$ (higher than three times $\mathrm{Al}_{2} \mathrm{O}_{3}$; Boström et al., 1972). These are explained by the occurrence of chert and by biogenic silica, as it has been observed in some samples in the clay fraction, from the dissolution of siliceous microfossils.

\section{DISCUSSION}

Some problems occur in this study, in particular the method of formation of smectites, clinoptilolite, and attapulgite in a carbonate environment under reducing conditions. Clinoptilolite either must be authigenic (Stonecipher, 1976; Couture, 1977; McCoy and Zimmermann, 1977), or it must form from alteration of volcanic material (Bonatti, 1963; Hathaway and Sachs, 1965; Kastner, 1976; McCoy and Zimmermann, 1977); it has been observed replacing radiolarians (Berger and von Rad, 1972). In Holes 465 and $465 \mathrm{~A}$, clinoptilolite apparently is not associated with volcanic detritus, but with biosiliceous debris in a high-carbonate environment 
Table 1. X-ray mineralogy of the sedimentary deposits of the Cretaceous/Tertiary boundary, Holes 465 and $465 \mathrm{~A}$.

\begin{tabular}{|c|c|c|c|c|c|c|c|c|c|c|c|c|}
\hline \multirow{2}{*}{$\begin{array}{c}\text { Sample } \\
\text { (interval in } \mathrm{cm} \text { ) }\end{array}$} & \multirow{2}{*}{$\begin{array}{l}\text { Sample } \\
\text { No. }\end{array}$} & \multirow[b]{2}{*}{ Lithology } & \multirow[b]{2}{*}{ Age } & \multicolumn{4}{|c|}{$\begin{array}{l}\text { Bulk-Sample Components } \\
\text { (non-orientated powders) }\end{array}$} & \multicolumn{5}{|c|}{$\begin{array}{l}<2-\mu \mathrm{m} \text {-Fraction Components } \\
\text { (orientated aggregates) }\end{array}$} \\
\hline & & & & Calcite & Quartz & Goethite & Pyrite & Smectite & Illite & Attapulgite & Sepiolite & Clinoptilolite \\
\hline $465-7, \mathrm{CC}$ & - & Nannofossil- & early & 100 & - & - & - & - & \multicolumn{4}{|c|}{ (not enough clay) } \\
\hline $465 A-3-1,30-32$ & 1 & foraminifer & Paleocene & 100 & - & - & - & 56 & 10 & 6 & - & 28 \\
\hline $465 A-3-6,30-32$ & 2 & ooze with chert & & 100 & tr & - & - & - & \multicolumn{4}{|c|}{ (not enough clay) } \\
\hline $465 \mathrm{~A}-3, \mathrm{CC}$ & 3 & and pyrite & & 75 & 25 & - & - & 46 & 18 & 15 & - & 21 \\
\hline $465 \mathrm{~A}-4, \mathrm{CC}$ & 4 & & & 30 & 20 & 50 & - & 100 & - & - & - & tr \\
\hline $465-10-1,70-72$ & 5 & Nannofossil ooze & late & 100 & - & - & - & 51 & 13 & 20 & - & 14 \\
\hline $465-10-2,70-72$ & 6 & and foraminifer- & Maastrichtian & 100 & tr & - & - & 49 & 18 & 7 & 9 & 15 \\
\hline $465-10-3,70-72$ & 7 & nannofossil ooze & & 100 & - & - & - & 62 & 11 & 9 & - & 17 \\
\hline $465-10-4,70-72$ & 8 & & & 100 & - & - & - & 65 & 10 & 9 & - & 15 \\
\hline $465-10-5,70-72$ & 9 & & & 100 & - & - & - & 71 & - & 13 & - & 16 \\
\hline $465-10, C C$ & 10 & & & 94 & 6 & - & - & 57 & 17 & - & - & 26 \\
\hline
\end{tabular}

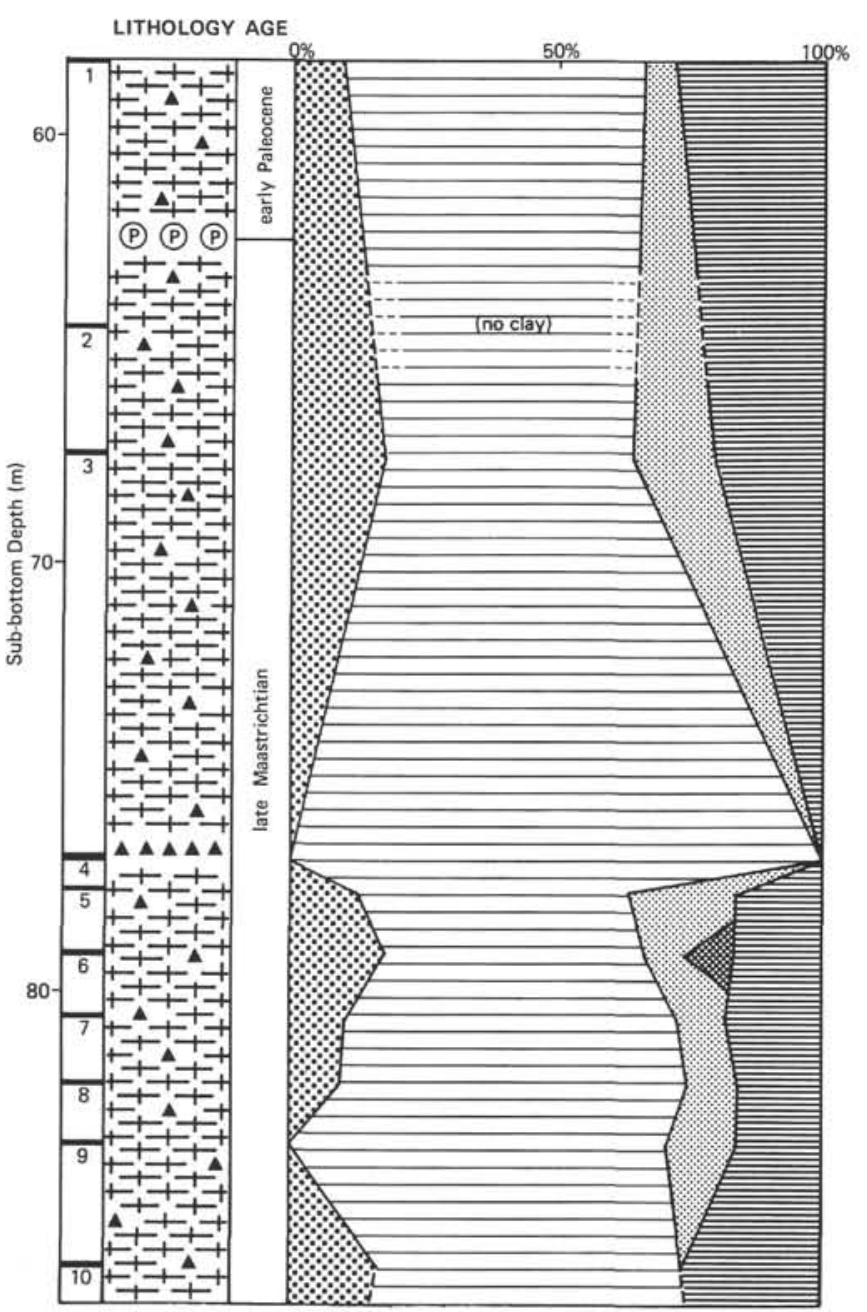

LITHOLOGY

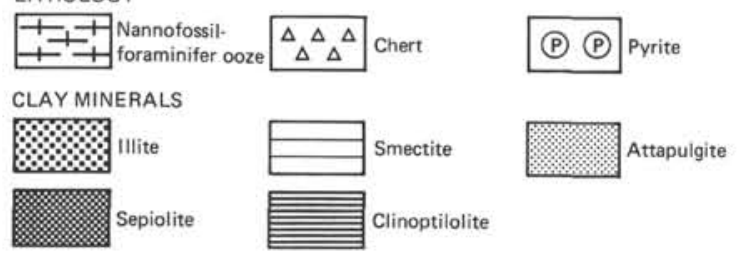

Figure 1. Abundance of clay minerals in Holes 465 and 465A. which favors the formation of zeolite (McCoy and Zimmermann, 1977). The authigenic formation of such minerals by the transformation of cation-enriched opal at depth to opal-CT, and ultimately quartz, was suggested by Donnelly and Merill (1977). Nathan and Flexer (1977) and Couture (1977) suggest that the presence of silica in active form (opal-CT) is a condition necessary for the formation of authigenic silicates by reaction with biogenic silica and interstitial water. Palygorskite (attapulgite-sepiolite) is widespread and abundant in Cretaceous clay and carbonate sediments of the Pacific (Couture, 1977). Several origins may be accepted: (1) directly precipitated from $\mathrm{Mg}$-rich brines in an arid zone (Millot, 1964; Rateev et al., 1969); (2) diagenetic formation from montmorillonite (Hathaway and Sachs, 1965); (3) continental origin, suggested by Chamley and Millot (1975) and Froget and Chamley (1977); (4) neoformation in a hydrothermal environment (Hathaway and Sachs, 1965; Bonatti and Joensuv, 1968; Church and Velde, 1979); (5) authigenic formation from opal-CT (Donnelly and Merill, 1977; Couture, 1977). Here it is not possible to fully resolve the problem of their method of formation. The present position in the Pacific of Holes 465 and $465 \mathrm{~A}$ favors authigenic or diagenetic formation over detrital input.

\section{ACKNOWLEDGMENTS}

I thank A. Schaaf for providing samples with the authorization of the Co-Chief Scientists of DSDP Leg 62. I express gratitude to A. M. Karpoff for assistance in preparation of this work. I am very much obliged to the assistance of geochemistry laboratory technicians of Centre de sedimentologie et Géochimie de la Surface of Strasbourg (France). Financial support for this work was provided by the CNEXO (Centre National pour l'exploitation des Océans (France) under Grant No. 3241.

\section{REFERENCES}

Ataman, G., and Besnus, Y., 1965. Une méthode de dosage des éléments traces dans les roches par spectrométrie à lecture directe. Bull. Serv. Carte Géol. Als. Lorr., 18 (4):176-189.

Berger, W. H., and von Rad, U., 1972. Cretaceous and Cenozoic sediments from the Atlantic Ocean. In Hayes, D. E., Pimm, A. C., et al., Init. Repts. DSDP, 14: Washington (U.S. Govt. Printing Office), 787-954.

Besnus, Y., and Lucas, J., 1970. Méthode de dosage de 18 éléments majeurs et traces dans les roches sédimentaires et les produits d'altération par spectrométrie à lecture directe. In Coll. Nat. C.N.R.S. No. 923. Dosage des éléments à l'état de traces dans les roches, Nancy, 1968, C.N.R.S. Ed., p. 93-106. 
Table 2. Chemistry of samples of the Cretaceous/Tertiary boundary, Holes 465 and 465A.

\begin{tabular}{|c|c|c|c|c|c|c|c|c|c|c|c|c|c|c|c|c|c|c|c|c|c|c|}
\hline \multirow{2}{*}{$\begin{array}{c}\text { Sample } \\
\text { (interval in } \mathrm{cm} \text { ) }\end{array}$} & \multirow{2}{*}{$\begin{array}{c}\text { Sample } \\
\text { No. }\end{array}$} & \multicolumn{10}{|c|}{$\begin{array}{l}\text { Major Elements } \\
\text { ( } \% \text { oxides) }\end{array}$} & \multirow[b]{2}{*}{$\mathrm{Sr}$} & \multirow[b]{2}{*}{$\mathrm{Ba}$} & \multirow[b]{2}{*}{ v } & \multirow[b]{2}{*}{$\mathrm{Ni}$} & \multicolumn{5}{|c|}{$\begin{array}{c}\text { Trace Elements } \\
\text { (ppm) }\end{array}$} & \multirow[b]{2}{*}{$\mathrm{Cu}$} & \multirow[b]{2}{*}{$\mathrm{Pb}$} \\
\hline & & $\mathrm{SiO}_{2}$ & $\mathrm{Al}_{2} \mathrm{O}_{3}$ & $\mathrm{MgO}$ & $\mathrm{CaO}$ & $\mathrm{Fe}_{2} \mathrm{O}_{3}$ & $\mathrm{Mn}_{3} \mathrm{O}_{4}$ & $\mathrm{TiO}_{2}$ & $\mathrm{Na}_{2} \mathrm{O}$ & $\mathrm{K}_{2} \mathrm{O}$ & L.O.I. & & & & & Co & $\mathrm{Cr}$ & B & $\mathrm{Zn}$ & $\mathrm{Ga}$ & & \\
\hline $465-7, \mathrm{CC}$ & - & 0.6 & $0.2 \mathrm{H}$ & 0.23 & 54.4 & $0.1 \mathrm{H}$ & 0.037 & $0.02 \mathrm{H}$ & 0.14 & $0.05 \mathrm{H}$ & 43.52 & - & - & - & - & - & - & - & - & - & - & - \\
\hline $465 A-3-1,30-32$ & 1 & 0.8 & 0.3 & 0.45 & 54.8 & $0.1 \mathrm{H}$ & 0.026 & 0.02 & 0.16 & $0.05 \mathrm{H}$ & 43.68 & 1422 & 1345 & $5 \mathrm{H}$ & 4 & $2 \mathrm{H}$ & $5 \mathrm{H}$ & 61 & $2 \mathrm{H}$ & $2 \mathrm{H}$ & 6 & 4 \\
\hline $465 A-3-6,30-32$ & 2 & 3.1 & $0.2 \mathrm{H}$ & 0.26 & 52.9 & 0.7 & 0.035 & $0.02 \mathrm{H}$ & 0.17 & $0.05 \mathrm{H}$ & 42.67 & 810 & 952 & $5 \mathrm{H}$ & $2 \mathrm{H}$ & $2 \mathrm{H}$ & $5 \mathrm{H}$ & 7 & $2 \mathrm{H}$ & $2 \mathrm{H}$ & 4 & 2 \\
\hline $465 \mathrm{~A}-3, \mathrm{CC}$ & 3 & 22.5 & $0.2 \mathrm{H}$ & 0.17 & 42.1 & $0.1 \mathrm{H}$ & 0.028 & $0.02 \mathrm{H}$ & 0.11 & $0.05 \mathrm{H}$ & 33.91 & 774 & 898 & $5 \mathrm{H}$ & 3 & $2 \mathrm{H}$ & $5 \mathrm{H}$ & $5 \mathrm{H}$ & $2 \mathrm{H}$ & $2 \mathrm{H}$ & 3 & $2 \mathrm{H}$ \\
\hline $465 \mathrm{~A}-4, \mathrm{CC}$ & 4 & 28.0 & 1.3 & 2.61 & 9.2 & 40.6 & 0.058 & 0.14 & 1.18 & 1.79 & 14.53 & - & - & - & - & - & - & - & - & - & - & - \\
\hline $465-10-1,70-72$ & 5 & 0.8 & $0.2 \mathrm{H}$ & 0.28 & 55.1 & $0.1 \mathrm{H}$ & 0.017 & $0.02 \mathrm{H}$ & 0.19 & $0.05 \mathrm{H}$ & 43.69 & 1027 & 980 & $\mathrm{SH}$ & $2 \mathrm{H}$ & $2 \mathrm{H}$ & $5 \mathrm{H}$ & $5 \mathrm{H}$ & $2 \mathrm{H}$ & $2 \mathrm{H}$ & 2 & 2 \\
\hline $465-10-2,70-72$ & 6 & 2.8 & $0.2 \mathrm{H}$ & 0.25 & 54.1 & $0.1 \mathrm{H}$ & 0.019 & $0.02 \mathrm{H}$ & 0.19 & $0.05 \mathrm{H}$ & 42.86 & 1363 & 702 & $5 \mathrm{H}$ & $2 \mathrm{H}$ & $2 \mathrm{H}$ & $5 \mathrm{H}$ & 51 & $2 \mathrm{H}$ & $2 \mathrm{H}$ & 2 & 2 \\
\hline $465-10-3,70-72$ & 7 & 1.1 & $0.2 \mathrm{H}$ & 0.28 & 55.0 & $0.1 \mathrm{H}$ & 0.016 & $0.02 \mathrm{H}$ & 0.17 & $0.05 \mathrm{H}$ & 43.79 & 1442 & 768 & $5 \mathrm{H}$ & $2 \mathrm{H}$ & $2 \mathrm{H}$ & $5 \mathrm{H}$ & 54 & $2 \mathrm{H}$ & $2 \mathrm{H}$ & 2 & 2 \\
\hline $465-10-4,70-72$ & 8 & 0.5 & $0.2 \mathrm{H}$ & 0.28 & 54.8 & $0.1 \mathrm{H}$ & 0.012 & $0.02 \mathrm{H}$ & 0.18 & $0.05 \mathrm{H}$ & 43.95 & 1246 & 741 & $5 \mathrm{H}$ & $2 \mathrm{H}$ & $2 \mathrm{H}$ & $5 \mathrm{H}$ & 12 & $2 \mathrm{H}$ & $2 \mathrm{H}$ & 5 & 2 \\
\hline $465-10-5,70-72$ & 9 & 0.8 & $0.2 \mathrm{H}$ & 0.28 & 54.9 & $0.1 \mathrm{H}$ & 0.022 & 0.02 & 0.22 & $0.05 \mathrm{H}$ & 43.84 & 1653 & 702 & $5 \mathrm{H}$ & $850 \mathrm{E}$ & $2 \mathrm{H}$ & 61 & 71 & $2 \mathrm{H}$ & 8 & 4 & 2 \\
\hline $465-10, \mathrm{CC}$ & 10 & 4.6 & $0.2 \mathrm{H}$ & 0.22 & 49.9 & $0.1 \mathrm{H}$ & 0.020 & $0.02 \mathrm{H}$ & 0.16 & $0.05 \mathrm{H}$ & 41.70 & 770 & 530 & $5 \mathrm{H}$ & $2 \mathrm{H}$ & $2 \mathrm{H}$ & $5 \mathrm{H}$ & $5 \mathrm{H}$ & $2 \mathrm{H}$ & $2 \mathrm{H}$ & $2 \mathrm{H}$ & 2 \\
\hline
\end{tabular}

Note: Major element oxides in percent of samples dried at $110^{\circ} \mathrm{C} ; \mathrm{L} . \mathrm{O} .1=$ loss on ignition at $1000^{\circ} \mathrm{C}$. Trace element values in ppm of samples dried at $110^{\circ} \mathrm{C} ; \mathrm{E}=$ extrapolated value; $-=$ no data; $\mathrm{H}=$ lower than the detection value.

Besnus, Y., and Rouault, R., 1973. Une methode d'analyse des roches au spectrometre d'arc à lecture directe par un dispositif d'électrode rotative. Analusis, 2:111-116.

Bonatti, E., 1963. Zeolites in Pacific pelagic sediments. N.Y. Acad. Sci. Trans., 25:938-948.

Bonatti, E., and Joensuv, O., 1968. Palygorskites from Atlantic deep sea sediments. Am. Mineral., $53(5,6): 975$.

Chamley, H., and Millot, G., 1975. Observation sur la répartition et la genèse des attapulgites plioquaternaires de Méditerranée. $C . R$. Acad. Sc., Paris, 281, Série D:1215-1218.

Church, T. M., and Velde, B., 1979. Geochemistry and origin of a deep-sea pelagic palygorskite deposit. Chem. Geol., 25:31-39.

Couture, R., 1977. Composition and origin of palygorskite-rich and montmorillonite-rich zeolite containing sediments from the Pacific Ocean. Chem. Geol., 19:113-130.

Donnelly, T. W., and Merill, L., 1977. The scavenging of magnesium and other chemical species by biogenic opal in deep sea sediments. Chem. Geol., 19:167-186.

Froget, C., and Chamley, H., 1977. Présence de sépiolite détritique dans les sédiments récents du golfe d'Arzew (Algérie). C. R. Acad. Sc., Paris, 285, Série D:307.

Hathaway, J. C., and Sachs, P. L., 1965. Sepiolites and clinoptilolite from the Mid-Atlantic Ridge. Am. Mineral., 50:852-866.
Kastner, M., 1976. Diagenesis of basal sediments and basalts of Sites 322 and 323, Leg 35, Bellingshaven Abyssal Plain. In Hollister, C. D., Craddock, C., et al., Init. Repts. DSDP, 35: Washington (U.S. Govt. Printing Office), 513-528.

McCoy, F. W., and Zimmerman, H. B., 1977. A history of sediment lithofacies in the South Atlantic Ocean. In Supko, P. R., PerchNielsen, K., et al., Init. Repts. DSDP, 39: Washington (U.S. Govt. Printing Office), 1047-1056.

Millot, G., 1964. Géologie des Argiles: Paris (Masson).

Nathan, Y., and Flexer, A., 1977. Clinoptilolite, paragenesis and stratigraphy. Sedimentol., 24:845.

Rateev, M. A., Gorbunova, Z. N., Lisitzin, A. T., et al., 1969. The distribution of clay minerals in the oceans. Sedimentol., 13:21-43.

Robert, M., and Tessier, D., 1974. Méthode de préparation des argiles des sols pour des études minéralogiques. Annales Agro., 25(6): 859-882.

Stonecipher, S. A., 1976. Origin, distribution and diagenesis of phillipsite and clinoptilolite in deep sea sediments. Chem. Geol., 17: 307-318.

Weber, F., and Larqué, P., 1978. Technique de préparation des minéraux argileux en vue de l'analyse par diffraction des Rayons $X$. Notes techniques de l'Institut de Géologie de Strasbourg (France). 

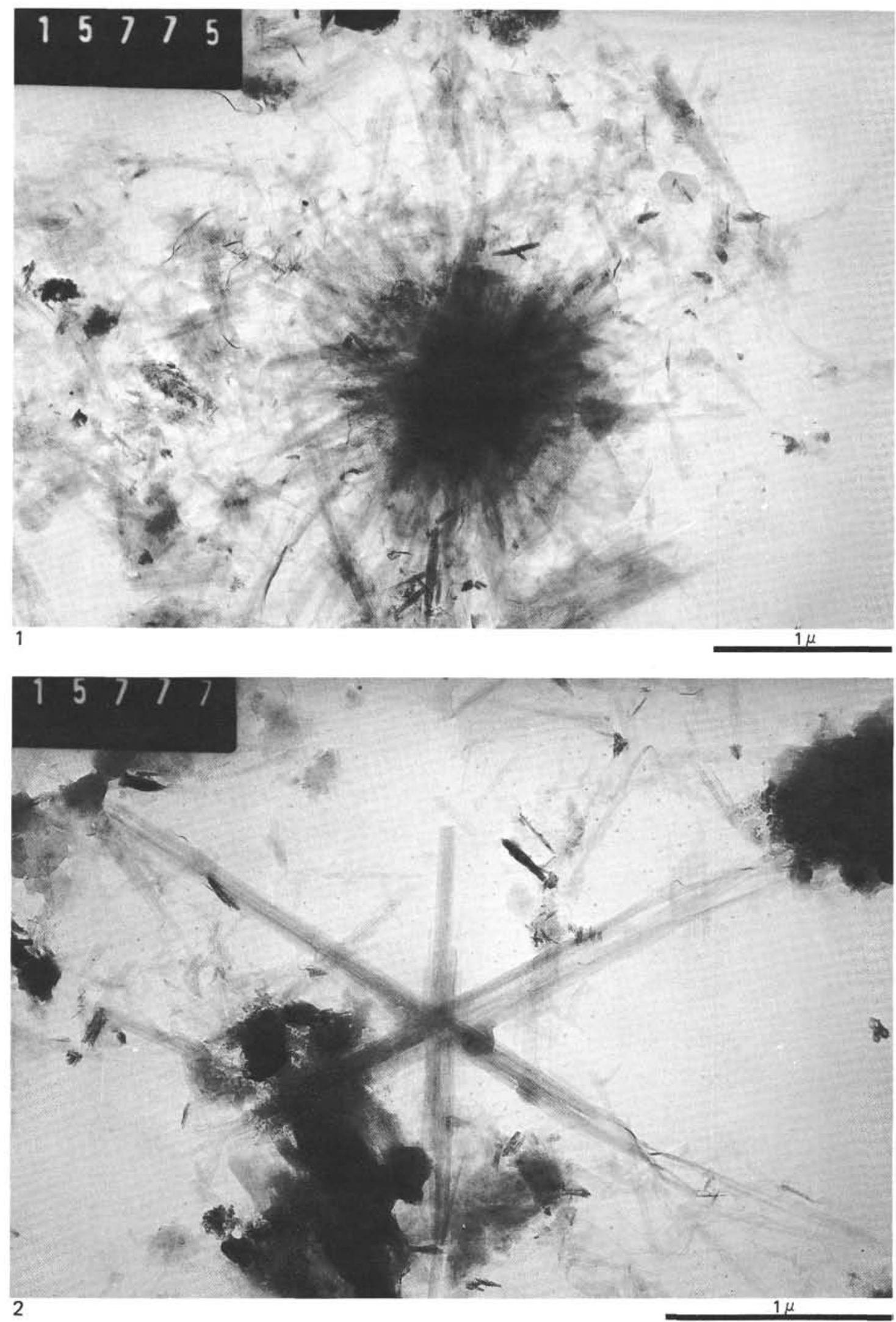

Plate 1. Transmission electron micrographs.

Figure 1. Transmission electron micrograph of the $<2-\mu \mathrm{m}$ fraction of $465 \mathrm{~A}-4, \mathrm{CC}$, showing a fibrous mineral.
Figure 2. Transmission electron micrograph of the $<2-\mu \mathrm{m}$ fraction of $465 \mathrm{~A}-4, \mathrm{CC}$, showing lath-shaped minerals. These minerals are described in the text as smectites. One can observed amorphous siliceous compounds associated with these lath-shaped minerals. 